\title{
Re-Establishing Stage 0 of COPD
}

\author{
Nikos Siafakas* \\ Department of Thoracic Medicine; University of Crete; Greece
}

Submission: May 04, 2017; Published: May 31, 2017

*Corresponding author: Nikos Siafakas; Emeritus Professor of Thoracic Medicine; University of Crete; Computer of Science Building; Room H307, 70013, Herakion, Crete, Greece; Tel: +30 6937215518; Email: siafak@med.uoc.gr; siafakan@uoc.gr

\section{Opinion}

Chronic Obstructive Pulmonary Disease (COPD) is a prevalent, with greater morbidity and mortality disease [1] COPD is the fourth leading cause of death, with more than 3 million deaths per year globally [2]. Its economic burden is enormous and had been the greatest challenge for all Health Systems in the world [3].

According to the last GOLD document, COPD is defined as: "a common, preventable and treatable disease that is characterized by persistent respiratory symptoms and airflow limitation that is due to airway and/or alveolar abnormalities usually caused by significant exposure to noxious particles and gases" [1,4].

The progressive airflow limitation has been shown by the classical work of Fletcher and Peto in the seventies and became the basis of the introduction of spirometry into the diagnosis of COPD $[5,6]$. A ratio of FEV1/FVC below 0.7 is now required to classify a patient with symptoms such as dyspnea, cough and sputum as COPD $[1,4]$.

Although the "preventable" element is stated in the definition, the disease is usually diagnosed very late and this has significant consequences on the natural history of the disease [4]. It is well known that the susceptible individual in order to develop the disease needs to be exposed to risk factors for long time, more than a decade $[1,4,6-7]$.

During this prolong pre-clinical period of the natural history of the disease significant changes occurs in the lungs on molecular and cellular level [8-12]. The small airways, in the periphery of the lungs, are usually the site where the initiation of those alterations could be detected [13]. Thereafter, those pathological changes may proceed towards the larger airways developing the phenotype of chronic bronchitis or towards the alveoli, causing emphysema or more commonly in both directions, developing the frequent phenotype of both entities (chronic bronchitis and emphysema) in the same patient, the so called COPD patient $[14,15]$.

During this phase of the disease the above morphological changes produce symptoms such as breathlessness, cough and sputum. Usually, these symptoms appear well before the functional changes could be detected by spirometry (FEV1/FVC $<0.7$ ). Recent studies had confirmed these observations showing that current or ex-smokers with preserved pulmonary function have symptoms, exacerbations and activity limitation equivalent that seen in COPD patients [14]

Thus, this early pre-clinical phase, according to the definition of COPD, is extremely important because if the disease is detected during this stage and managed appropriately, the natural history of the disease may be altered immensely. Previously, this subclinical stage was defined as STAGE 0 by the first guideline documents by GOLD but it disappeared from the subsequent ones $[1,15]$.

Since, during this long pre-clinical phase of the natural history of the disease the most significant molecular, cellular and histological changes occur, it would be of great scientific value to focus our research on it [16].

Therefor, I do recommend the re -establishment of Stage 0 of COPD, defining the patients with exposure to risk factors, having the symptoms of the disease (dyspnea, cough and sputum), but with preserved lung function. I do believe, that if we have STAGE 0 back in the guidelines, we will enhance the research on the pathophysiology of its early phase, in other wards, at the beginning of COPD $[16,17]$. In addition, STAGE 0 will increase the awareness of the disease and if the appropriate measures will be taken ,this would modify the natural history of COPD, reducing immensely the burden the disease..

\section{References}

1. GOLD (2016) Global Strategy For The Diagnosis, Management, and Prevention of COPD-2016. Global Initiative for Chronic Obstructive Lung Disease.

2. Halbert RJ, Natoli JL, Gano A, Badamgarav E, Buist AS, et al. (2006) Global burden of COPD: systematic review and meta-analysis. Eur Respir J 28(3): 523-532.

3. WHO (2017) Chronic Respiratory Diseases: Burden of COPD. Word Health Organisation, Geneva, Switzerland.

4. Celli BR, MacNee W (2004) Standards for the diagnosis and treatment 
of patients with COPD: a summary of the ATS/ERS position paper. Eur Respir J 23(6): 932-946.

5. Fletcher C, Peto R (1977) The natural history of chronic airflow obstruction. Br Med J 1(6077): 1645-1648.

6. Fletcher CM, Peto R (1976) The Natural History of Chronic Bronchitis and Emphysema. Br Med J 1(6077): 1645-1648.

7. Siafakas NM, Vermeire P, Pride NB, Paoletti P, Gibson J, et al. (1995) Optimal assessment and management of chronic obstructive pulmonary disease (COPD). Eur Respir J 8(8): 1398-1420.

8. Tzortzaki EG, Siafakas NM (2009) A hypothesis for the initiation of COPD. Eur Respir J 34(2): 310-315.

9. Cosio MG, Saetta M, Agusti A (2009) Immunologic Aspects of Chronic Obstructive Pulmonary Disease. N Engl J Med 360(23): 2445-2454.

10. Brusselle GG, Joos GF, Bracke KR (2011) Chronic Obstructive Pulmonary Disease $1 \mathrm{New}$ insights into the immunology of chronic obstructive pulmonary disease. Lancet 378(9795): 1015-1026.

11. Chrysofakis G, Tzanakis N, Kyriakoy D, Tsoumakidou M, Tsiligianni I, et al. (2004) Perforin Expression and Cytotoxic Activity of Sputum CD8+ Lymphocytes in Patients With COPD. Chest 125(1): 71-76.
12. Barnes PJ (2014) Cellular and Molecular Mechanisms of Chronic Obstructive Pulmonary Disease. Clin Chest Med 35(1): 71-86.

13. Hogg JC, Chu F, Utokaparch S, Woods R, Elliott WM, et al. (2004) The nature of small-airway obstruction in chronic obstructive pulmonary disease. N Engl J Med 350(26): 2645-2653.

14. Woodruff PG, Barr RG, Bleecker E, Christenson SA, Couper D, et al (2016) Clinical Significance of Symptoms in Smokers with Preserved Pulmonary Function. N Engl J Med 374(19): 1811-1821.

15. Pauwels RA, Buist AS, Calverley PMA, Jenkins CR, Hurd SS (2001) NHLBI/WHO Workshop Summary Global Strategy for the Diagnosis, Management, and Prevention of Chronic Obstructive Pulmonary Disease NHLBI/WHO Global Initiative for Chronic Obstructive Lung Disease (GOLD) Workshop Summary. Am J Respir Crit Care Med 163(5): 1256-1276.

16. Siafakas N (2007) “In the Beginning” of COPD - Is Evolution Important? Am J Respir Crit Care Med 175(5): 423-425.

17. Celli BR, Decramer M, Wedzicha JA, Wilson KC, Agustí AA, et al. (2015) An official American Thoracic Society/European Respiratory Society statement: research questions in COPD. Am J Respir Crit Care Med 191(7): e4-e27.

\section{Your next submission with Juniper Publishers} will reach you the below assets

- Quality Editorial service

- Swift Peer Review

- Reprints availability

- E-prints Service

- Manuscript Podcast for convenient understanding

- Global attainment for your research

- Manuscript accessibility in different formats

(Pdf, E-pub, Full Text, Audio)

- Unceasing customer service

Track the below URL for one-step submission https://juniperpublishers.com/online-submission.php 